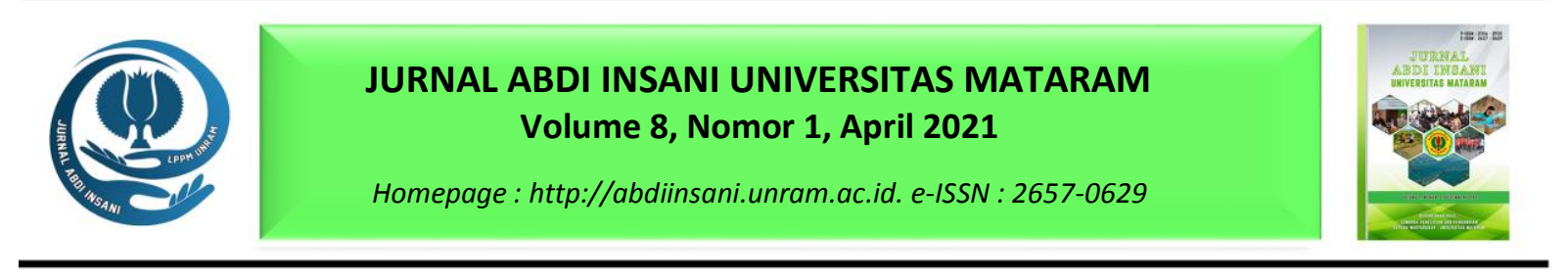

\title{
PENYULUHAN HUKUM TENTANG EXECUTIE OBYEK JAMINAN FIDUCIA DI DESA GELOGOR KABUPATEN LOMBOK BARAT
}

\section{Legal Counseling About Executie Object Fidusia Assurance In Gelogor Village, West Lombok District}

\author{
Hirsanuddin, Sudiarto, Lalu Wira Pria Suhartana \\ Jurusan Hukum Bisnis Fakultas Hukum Universitas Mataram \\ JI. Majapahit No.62, Gomong, Kec. Selaparang, Kota Mataram, Nusa Tenggara Bar. 83115 \\ *Alamat korespondensi: hirsanuddin@unram.ac.id
}

(Tanggal Submission: 28 Maret 2021, Tanggal Accepted : 28 April 2021)

\begin{abstract}
Keyword: Abstract :
Jaminan Jaminan fidusia adalah hak jaminan atas benda bergerak baik yang berwujud maupun tidak Fidusia, berwujud dan benda tidak bergerak. Berdasarkan ketentuan Pasal 30 UU Fidusia "Pemberi Fidusia Debitor, wajib menyerahkan benda yang menjadi objek jaminan dalam rangka pelaksanaan eksekusi Kreditor jaminan Fidusi Permasalahan yang sering muncul pada kasus ini adalah apabila debitor tidak memberikan benda jaminan secara sukarela, kreditor seringkali melakukan tindakan paksa untuk mengambilnya. Kegiatan pengabdian kepada masyarakat ini bertujuan untuk memberikan informasi mengenai hal-hal apa saja yang harus dilakukan jika mengalami hal tersebut. Metode yang digunakan dalam penyuluhan ini menggunakan metode ceramah yang diikuti dengan tanya jawab. Kegiatan dilanjutkan dengan sesi tanya jawab. Masyarakat gelogor kurang mendapat informasi mengenai executie obyek jaminan fiducia. Hal ini dapat terlihat dari antusian masyarakat dalam memberikan pertanyaan terkait meteri yang kami berikan. mereka tidak mengatahui akibat hukum yang ditimbulkan dari tidak dilaksanakan kewajibannya pada bank. Sehingga banyak dari pemberi fidusia yang menggadaikan emasnya pada lembaga penggadaian dengan tujuan mengembalikan pinjaman yang menunggak tersebut. Serta masyarakat juga kurang memahai akibat lain dari tidak dilaksanakan kewajiban dari pemberi fidusia, yaitu barang jaminan, berupa benda bergerak dilelang oleh lembanga perbankan, melalui Kantor Lelang Negara. Sehingga dapat di desa gelogor perlu diadakan penyuluhan hukum yang berkelanjutan untuk tema yang seperti ini.
\end{abstract}

Panduan sitasi / Citation guidance (APPA $7^{\text {th }}$ edition) :

Hirsanuddin, Sudiarto, \& Suhartana, L. W. P. (2021). Penyuluhan Hukum Tentang Executie Obyek Jaminan Fiducia Di Desa Gelogor Kabupaten Lombok Barat. Jurnal Abdi Insani Universitas Mataram, 8 (1), 118125. http://doi.org/10.29303/abdiinsani.v8i1.387 


\section{PENDAHULUAN}

Sering dipersoalkan mengenai kapan sebenarnya hak untuk melakukan penjualan objek jaminan atas kekuasaan sendiri itu muncul, apakah pada saat perjanjian mengenai penjaminan atas pembiayaan yang diberikan itu disepakati ataukah pada saat debitor mulai dinyatakan dalam keadaan wanprestasi. Memang benar bahwa hak parate eksekusi selalu disepakati di awal perjanjian, atau bahkan tanpa disadari oleh para pihak bahwa hak tersebut timbul karena dalam beberapa hal klausul kekuasaan untuk melakukan penjualan atas kekuasaan sendiri telah tercantum dalam formulir akta pembebanan jaminan, namun demikian jika kita telaah kembali bahwa ketika perjanjian pokoknya (Perjanjian Pembiayaan Konsumen/Perjanjian Kredit) berjalan dengan lancar dan tidak mengalami kemacetan, apakah mungkin kekuasaan untuk melakukan penjualan benda jaminan (parate eksekusi) itu sudah ada di tangan kreditor? Mungkin kita dapat mengkonstruksikan bahwa hak itu memang telah dibuat atau telah ada sejak disepakatinya perjanjian jaminan oleh para pihak, namun hak tersebut tidak dapat digunakan jika perjanjian pokoknya berjalan lancar atau setidaknya masih terhalangi oleh sebuah syarat tertentu, karena pelunasan utang menggunakan benda jaminan merupakan upaya substansi jika debitor tidak melakukan prestasinya dengan pembayaran secara normal (Witanto ,2015).

Dengan menggunakan logika di atas berarti kewenangan parate eksekusi yang sejak semula telah dipegang oleh kreditor tersebut baru dapat digunakan sejak debitor dalam keadaan wanprestasi, jika sampai dengan berakhirnya masa perjanjian ternyata tidak terjadi wanprestasi, maka kewenangan parate eksekusi tersebut tidak dapat digunakan oleh kreditor dan akan gugur dengan sendirinya sejak utang yang dijamin oleh jaminan tersebut dibayar lunas, karena sebagaimana sifat accesoir dari perjanjian jaminan yang selalu mengikuti perjanjian pokoknya, maka begitu peijanjian pokoknya selesai, dengan sendirinya perjanjian jaminan itu pun akan turut menjadi hapus.

Jika parate eksekusi itu baru dapat digunakan ketika debitor wanprestasi lalu sebenarnya sejak kapan debitor dalam perjanjian pembiayaan/perjanjian kredit dapat dikatakan wanprestasi? Dalam perjanjian yang telah menentukan batas waktu pembayarannya, maka waktu saat debitor wanprestasi akan diatur berdasarkan klausula perjanjiannya. Dalam perjanjian kredit yang menentukan kewajiban cicilan pada setiap bulannya, maka kategori wanprestasi akan ditentukan berdasarkan batas waktu pembayaran cicilan, misalnya dalam perjanjian kredit bank ditentukan bahwa debitor berkewajiban untuk melakukan pembayaran cicilan paling lambat tanggal 10 pada setiap bulannya, jika debitor lalai tidak melakukan prestasi sebagaimana yang telah disepakati, maka sejak saat itu kreditor telah bisa menggunakan haknya untuk melakukan parate eksekusi walaupun secara kepatutan mestinya pihak bank akan melakukan somasi terlebih dahulu barangkali debitor memang lupa atau sedang tidak berada di tempat sehingga tidak sempat/tidak mampu untuk melaksanakan kewajiban pembayarannya bahkan pada umumnya eksekusi jaminan baru dilaksanakan oleh pihak bank/kreditor jika debitor telah benar-benar berhenti membayar sampai beberapa kali cicilan.

Pasal 1238 KUH Perdata menyebutkan bahwa "debitor dinyatakan lalai dengan surat perintah atau dengan akta sejenis itu atau berdasarkan kekuatan dan perikatan sendiri yaitu bila perikatan itu mengakibatkan debitor harus dianggap telah dengan lewatnya waktu yang ditentukan". Dalam perjanjian perbankan hampir tidak ada perjanjian yang tidak ditentukan masa waktu pembayarannya karena semua bentuk penjanjian kredit yang dilakukan antara bank dengan nasabah termasuk juga dalam perjanjian pembiayaan, selalu telah dibuat dalam bentuk standar baku sehingga pihak debitor (nasabah) pada 
umumnya tidak mempelajari lagi isi penjanjian yang disodorkan kehadapannya ia tinggal menentukan sikap apakah setuju dengan menandatanganinya atau menolaknya.

Semua nilai tagihan kreditor berdasarkan perjanjian yang disepakati dapat dilakukan pelunasan berdasarkan penjualan objek jaminan, jika dari hasil penjulan lelang objek jaminan itu melebihi dari kewajiban pembayaran utang-utang debitor, semua kelebihan yang ada akan diserahkan kembali kepada si pemilik jaminan, namun dalam hal ternyata nilai penjualan objek jaminan kurang dari nilai hutang debitor, maka kreditor dapat melakukan eksekusi atas benda lain milik debitor, namun prosesnya tidak dapat lagi dilakukan menggunakan kewenangan parate eksekusi akan tetapi melalui proses gugatan biasa ke hadapan hakim. Hal seperti demikian jarang sekali terjadi mengingat pada saat penilaian objek jaminan setidak-tidaknya nilai jaminan harus melebihi dari nilai utang yang diberikan, baik dalam perjanjian kredit maupun perjanjian pembiayaan pemberian kredit tidak boleh melebihi $70 \%$ nilai jaminan, hal ini untuk menjaga kemungkinan adanya penurunan nilai objek jaminan dan biaya-biaya yang mungkin timbul dari proses eksekusi.

Dalam melakukan penjualan lelang dengan menggunakan kewenangan parate eksekusi; nilai utang pokok berikut bunganya dan segala biaya-biaya yang harus dibayar oleh debitor harus jelas dan pasti berdasarkan perhitungan tagihan terakhir atau nilai utang yang diberikan ditambah dengan bunga, denda dan biaya-biaya lain, namun dikurangi dengan jumlah pembayaran yang pernah dilakukan. Jika terjadi perselisihan mengenai nilai utang dan bunga, maka debitor dapat mengajukan gugatan ke pengadilan dan pengadilan akan memerintahkan untuk tidak dilakukan parate eksekusi sebelum nilai hutangnya menjadi jelas berdasarkan putusan pengadilan. Keberatan atas nilai hutang dan bunga bukan hanya semata-mata keberatan tanpa didukung dengan bukti-bukti yang cukup, jika keberatan tersebut dipandang hanya sekedar untuk menghambat hak kreditor untuk melakukan parate eksekusi, maka pengadilan tidak perlu untuk memerintahkan penundaan pelaksanaan eksekusi, hal ini untuk menjaga kepentingan si pemegang jaminan agar dapat melakukan pelunasan dengan cepat dan mudah.

Kemungkinan kasus seperti di atas terjadi ketika debitor tidak mau barang jaminannya dijual lelang lalu kemudian mengajukan gugatan ke pengadilan dengan maksud untuk mengulur-ulur waktu, sehingga pengadilan tidak boleh melindungi kepentingan debitor yang demikian.

Setiap perjanjian timbal balik akan menimbulkan hak dan kewajiban kepada masing-masing pihak yang kemudian disebut perikatan. Atas timbulnya hak dan kewajiban tersebut, maka mereka yang menyandang hak dan hubungan hukum itu disebut "kreditor" dan lawan daripadanya sebagai pemegang kewajiban disebut "debitor." Pada saat perjanjian disepakati, maka akan timbul hak dan kewajiban terhadap para pihak, hal $\mathrm{ml}$ sebagai konsekuensi dan suatu perjanjian ob/igatoir yang dianut oleh Buku III KUH Perdata (BW).

Perjanjian jaminan merupakan perjanjian assesoiratau penjanjian yang menempel pada perjanjian lain sebagai perjanjian pokoknya. Pada asasnya perjanjian jaminan timbul karena adanya penjanjian utang piutang atau perjanjian yang menimbulkan kewajiban berupa pembayaran uang, sehingga keberadaannya tidak bisa terlepas dari perjanjian pokoknya yaitu hubungan utang-piutang. Kreditor merupakan istilah umum untuk orang yang berhak atas suatu prestasi tertentu dalam suatu perikatan pada umumnya, atau dapat juga dirumuskan sebagai pihak yang berpiutang dalam suatu hubungan utang piutang tertentu. Dalam perjanjian jaminan yang menjadi kreditor adalah si pemberi utang, berdasarkan kesepakatan dan janji Kedudukan kreditor yang memiliki hak untuk melakukan penjualan atas kekuasaannya sendiri 
berdasarkan Pasal 1178 Ayat (2) dan Pasal 1155 Ayat (1) KUH Perdata merupakan konsekuensi atas adanya kuasa mutlak yang diberikan oleh debitor. Pengertian kuasa mutlak sebagaimana disebutkan dalam kalimat "secara mutlak akan dikuasakan" tidak akan berakhir oleh sebab apapun kecuali jika si pemegang jaminan sendiri yang merelakan agar kuasa/hak itu dicabut atau diserahkan kembali kepada si pemberinya.

Menurut M. Khoidin, disebut dengan jaminan khusus yang memberikan sarana khusus (parate eksekusi) kepada kreditur untuk melakukan eksekusi secara paksa apabila debitor wanprestasi (Khoidin, 2017).

Kedudukan seorang kreditor yang memiliki hak parate eksekusi selalu mempunyai hak untuk mendahului karena kedudukan seorang kreditor atas hak untuk melakukan penjualan atas kekuasaan sendiri adalah kreditor pemegang jaminan pertama, sehingga dapat dikatakan bahwa diantara pemegang jaminan yang lainnya atau diantara yang sama-sama sebagai kreditor preferen. Kreditor yang memiliki kewenangan parate eksekusi selalu menempati posisi yang paling tinggi, hal ini sesuai dengan asas hukum dalam menentukan peringkat jaminan kebendaan, dimana jaminan kebendaan yang lahir lebih dulu menempati urutan yang lebih tinggi dan kewenangan parate eksekusi hanya dimiliki oleh pemegang jaminan kebendaan pertama.

Dalam proses eksekusi Jaminan Fidusia akan didahului dengan pngambilalihan penguasaan benda jaminan dan tangan debitor oleh kreditor, mengingat sebelumnya benda jaminan tersebut berada dalam kekuasaan debitor. Berdasarkan ketentuan Pasal 30 UU Fidusia "Pemberi Fidusia wajib menyerahkan benda yang menjadi objek jaminan dalam rangka pelaksanaan eksekusi jaminan Fidusi" yang selalu menjadi pertanyaan adalah jika debitor tidak memberikan benda jaminan itu secara sukarela, apakah kreditor berwenang untuk mengambil secara paksa? Memang tidak ada ketentuan yang secara tegas menyebutkan bahwa kreditor berhak untuk mengambil objek jaminan secara paksa dan penguasaan debitor, namun dan ketentuan Penjelasan dalam Pasal 30 UU Fidusia yang menyebutkan bahwa "dalam hal Pemberi Fidusia tidak menyerahkan benda yang menjadi objek Jaminan Fidusia pada waktu eksekusi dllaksanakan, Penerima Fidusia berhak mengambil benda yang menjadi objek Jaminan Fidusia dan apabila perlu dapat meminta bantuan pihak yang berwenang." maka dapat disimpulkan bahwa kreditor dapat mengambil objek jaminan tersebut secara paksa dengan catatan bahwa pengambilan tersebut melalui bantuan pihak yang berwenang.

Pada saat debitor tidak menyerahkan objek Jaminan Fidusia, maka kreditor dapat memintanya kepada pihak debitor, namun jika debitor tetap mempertahankannya, maka kreditor tidak perlu untuk memaksanya dengan tangannya sendiri karena undang-undang telah memberikan pengaturan bahwa kreditor dapat meminta bantuan pihak yang berwenang untuk mengambilnya atau setidaknya mendampingi pada saat pengambilan benda jaminan tersebut. Dan ketentuan tersebut dimungkinkan bahwa pengambilan secara paksa itu dilakukan oleh pihak yang berwenang, yang dalam hal ini tentunya pihak Kepolisian Republik Indonesia.

Oleh karena itu, berdasarkan penjelasan di atas dilakukanlah Penyuluhan Hukum Tentang Executie Obyek Jaminan Fiducia yang bertujuan memberi pemahaman kepada masyarakat khususnya yang ada di Desa Gelogor mengenai akibat hukum yang ditimbulkan dari tidak dilaksanakan kewajibannya pada lembaga penyedia dana. 


\section{METODE KEGIATAN}

Kegiatan penyuluhan ini menggunakan metode ceramah yang diikuti dengan tanya jawab dan yang menjadi sasaran pada kegiatan ini adalah oleh staf desa, yang dimana peserta penyuluhan ini terdiri dari Kepala Desa, Sekretaris Desa, Kepala Dusun, Ketua BPD (Badan Perwakilan Desa) dan anggota BPD, Karang Taruna, PNS, Tokoh/pemuka masyarakat, Petani, dan anggota masyarakat pada umumnya. Hal pertama yang dilakukan pengumpulan peserta yang dimana peserta penyuluhan ini terdiri dari Kepala Desa, Sekretaris Desa, Kepala Dusun, Ketua BPD (Badan Perwakilan Desa) dan anggota BPD, Karang Taruna, PNS, Tokoh/pemuka masyarakat, Petani, dan anggota masyarakat pada umumnya. Sehinga jumlah peserta yang hadir sebanyak 36 orang dan peserta yang paling banyak adalah petani dengan jumlah 27 orang.

Kemudian dilakukan penyampaian materi tentang lembaga keuangan sebagai salah satu fasilitator penyedia dana berupa pinjaman kredit, dampak jika debitur lalai mengembalikan uang pinjaman pada saat yang telah diperjanjikan, dan pengertian jaminan fidusia. Setelah ceramah disampaikan, kemudian dibuka sesi tanya jawab dimana peserta menanyakan kembali kepada anggota tim penyuluh tentang hal-hal yang belum jelas atau belum dimengerti. Tolak ukurnya pada kegiatan penyuluhan ini adalah tingkat keseriusan peserta dalam mengikuti kegiatan penyuluhan dan tingkat pemahaman peserta yang dinilai dari pertanyaan-pertanyaan yang diajukan oleh para peserta.

\section{HASIL DAN PEMBAHASAN}

Kegiatan penyuluhan ini dihadiri oleh staf desa, yang dimana peserta penyuluhan ini terdiri dari Kepala Desa, Sekretaris Desa, Kepala Dusun, Ketua BPD (Badan Perwakilan Desa) dan anggota BPD, Karang Taruna, PNS, Tokoh/pemuka masyarakat, Petani, dan anggota masyarakat pada umumnya. Kemudian dijelaskan mengenai mengenai executie obyek jaminan fiducia.

\section{lembaga keuangan sebagai salah satu fasilitator penyedia dana berupa pinjaman kredit}

Keberadaan lembaga keuangan sangatlah dibutuhkan sebagai salah satu fasilitator penyedia dana berupa pinjaman kredit bagi pengusaha yang membutuhkan tambahan dana bagi kelangsungan usahanya. Bank sebagai salah satu bentuk dari lembaga keuangan merupakan institusi yang dibentuk sebagai upaya untuk mendukung kegiatan ekonomi masyarakat. Bank yang bekerja berdasarkan kepercayaan masyarakat, memiliki peran dan posisi strategis dalam pembangunan nasional.

Pada dasarnya, pemberian kredit oleh bank dapat diberikan kepada siapa saja yang memiliki kemampuan, untuk itu melalui perjanjian utang piutang anatara pemberi utang (kreditur) disatu pihak dan penerima utang (debitur) di lain Pihak. Setelah perjanjian tersebut disepakati, maka lahirlah kewajihan pada diri kreditur, yaitu untuk menyerahkan uang yang diperjanjikan kepada debitur, dengan hak untuk menerima kembali uang itu dari debitur pada waktunya, disertai dengan bunga yang disepakati oleh para pihak pada saat perjanjian pemberian kredit tersebut disetujui oleh para pihak. Hak dan kewajiban debitur adalah bertimbal balik dengan hak dan kewajiban kreditur. Selama proses ini tidak menghadapi masalah dalam arti kedua pihak melaksanakan hak dan kewajibannya sesuai dengan yang diperjanjikan, maka persoalan tidak akan muncul. 


\section{Jaminan Fidusian dan Dampak jika lalai mengembalikan uang pinjaman}

Fidusia adalah pengalihan hak kepemilikan suatu benda atas dasar kepercayaan dengan ketentuan bahwa benda yang hak kepemilikannya dialihkan tersebut tetap dalam penguasaan pemilik benda. Hal tersebut tertuang dalam Undang-Undang Nomor 42 Tahun 1999 tentang Jaminan Fidusia (www.wartaekonomi.co.id).

Fidusia menurut asal katanya berasal dari bahasa Romawi fides yang berarti kepercayaan. Fidusia merupakan istilah yang sudah lama dikenal dalam bahasa Indonesia. Begitu pula istilah ini digunakan dalam Undang-undang Nomor 42 Tahun 1999 tentang Jaminan Fidusia. Dalam terminologi Belanda istilah ini sering disebut secara lengkap yaitu Fiduciare Eigendom Overdracht (F.E.O.) yaitu penyerahan hak milik secara kepercayaan. Sedangkan dalam istilah bahasa Inggris disebut Fiduciary Transfer of Ownership (https://id.wikipedia.org).

Dalam memenuhi kebutuhan masyarakat yang terus berkembang dalam hal memperoleh pinjaman atau pembiayaan, kegiatan bank maupun lembaga non bank dalam memberikan pinjaman berdasarkan perjanjian jaminan Fidusia merupakan salah satu solusi yang tepat, sebab pemberian pinjaman atau pembiayaan dengan jaminan Fidusia memberikan kemudahan kepada debitur khususnya. Terutama bagi kalangan masyarakat ekonomi kebawah dimana debitur selain memperoleh pinjaman atau pembiayaan juga tetap menguasai benda yang dijaminkan untuk menjalankan kegiatan usahanya.

Dari pengertian jaminan fidusia tersebut maka bisa ditentukan unsur-unsur jaminan fidusia yakni :

1. Adanya hak jaminan

2. Adanya objek yaitu benda bergerak baik yang berwujud maupun yang tidak berwujud dan benda tidak bergerak, khususnya bangunan yang tidak dibebani hak tanggungan.

3. Benda menjadi objek jaminan tetap berada dalam penguasaaan pemberi fidusia.

4. Memberikan kedudukan yang diutamakan kepada kreditur.

Dalam ketentuan Pasal 11 ayat (1) Undang-undang No. 42 Tahun 1999 Tentang Jaminan Fidusia, bahwa benda yang dibebani dengan Jaminan Fidusia wajib didaftarkan". Kemudian dalam ketentuan Pasal 12 ayat (1) menyebutkan bahwa "Pendaftaran Jaminan fidusia sebagaimana dimaksud dalam Pasal 11 ayat (1) dilakukan pada Kantor Pendaftaran Fidusia". Sebagaimana yang diatur dalam Undang-undang No. 12 Tahun 2011 Tentang Pembentukan Peraturan Perundang-undangan bahwa frasa kata "wajib" yang apabila terjadi pelanggaran terhadap bunyi Pasal tersebut atau dengan kata lain bahwa Pasal tersebut tidak dilaksanakan, maka akan ada sanksi yang diberikan kepada pelanggar, baik berupa sanksi pidana seperti yang tertuang dalam Pasal 10 KUHP atau sanksi yang bersifat administratif.

Pelaksanaan pemberian kredit pada umumnya, dilakukan dengan dibuatnya suatu perjanjian. Perjanjian tersebut terdiri dari perjanjian pokok, yaitu perjanjian utang-piutang dan setelah itu dilanjutkan dengan perjanjian tambahan yaitu berupa perjanjian pemberian jaminan oleh pihak debitur.

Perjanjian pembebanan jaminan fidusia dimaksud untuk mengantisipasi jika debitur tidak mampu membayar atau debitur wanprestasi. Untuk melindungi kreditur dari kelalaian atau ketidakmampuan debitur dalam melunasi kewajibannya atau hutangnya maka Pasal 15 Undang-Undang Nomor 42 tentang Jaminan Fidusia yang selanjutnya disebut Undang-Undang Jaminan Fidusia mengatur bahwa :

1. Dalam Sertifikat Jaminan Fidusia sebagaimana dimaksud dalam Pasal 14 ayat (1) dicantumkan katakata "DEMI KEADILAN BERDASARKAN KETUHANAN YANG MAHA ESA". 
2. Sertifikat Jaminan Fidusia sebagaimana dimaksud dalam ayat (1) mempunyai kekuatan eksekutorial yang sama dengan putusan pengadilan yang telah memperoleh kekuatan hukum tetap.

3. Apabila debitor cidera janji, Penerima Fidusia mempunyai hak untuk menjual Benda yang menjadi objek Jaminan Fidusia atas kekuasaannya sendiri.

Pasal 29 Undang-Undang Jaminan Fidusia menyatakan bahwa apabila debitor atau pemberi fidusia cidera janji, eksekusi terhadap benda yang menjadi obyek jaminan fidusia dapat di lakukan dengan cara :

1. Pelaksanaan titel eksekutorial sebagaimana dimaksud dalam Pasal 15 ayat (2) oleh Penerima Fidusia;

2. Penjualan benda yang menjadi objek Jaminan Fidusia atas kekuasaan Penerima Fidusia sendiri melalui pelelangan umum serta mengambil pelunasan piutangnya dari hasil penjualan;

3. penjualan di bawah tangan yang dilakukan berdasarkan kesepakatan Pemberi dan Penerima Fidusia jika dengan cara demikian dapat diperoleh harga tertinggi yang menguntungkan para pihak.

Perjanjian fidusia adalah perjanjian hutang piutang kreditor kepada debitor yang melibatkan penjaminan. Jaminan tersebut kedudukannya masih dalam penguasaan pemilik jaminan, dan untuk menjamin kepastian hukum bagi kreditor maka dibuatkata yang dibuat oleh notaris dan didaftarkan ke kantor pendaftaran fidusia untuk mendapatkan sertifikat jaminan fidusia yang memiliki kekuatan hak eksekutorial langsung apabila debitor melakukan pelanggaran perjanjian fidusia kepada kreditor menurut Undang-Undang No.42 Tahun 1999 tentang Jaminan Fidusia.

Jika penerima fidusia mengalami kesulitan di lapangan, maka ia dapat meminta pengadilan setempat melalui juru sita membuat surat penetapan permohonan bantuan pengamanan eksekusi. Bantuan pengamanan eksekusi ini bisa ditujukan kepada aparat kepolisian, pamong praja dan pamong desa/kelurahan dimana benda objek jaminan fidusia berada. Dengan demikian bahwa pembuatan sertifikat jaminan fidusia melindungi penerima fidusia jika pemberi fidusia gagal memenuhi kewajiban sebagaimana tertuang dalam perjanjian kedua belah pihak.

Fakta dilapangan menunjukan, lembaga pembiayaan dalam melakukan perjanjian pembiayaan mencamtumkan kata-kata dijaminkan secara fidusia. Tetapi ironisnya tidak dibuat dalam akta notaris dan tidak didaftarkan di Kantor Pendaftaran Fidusia untuk mendapat sertifikat. Akta ini dapat disebut akta jaminan fidusia di bawah tangan. Jaminan fidusia yang tidak dibuatkan sertifikat jaminan fidusia menimbulkan akibat hukum yang komplek dan beresiko. Kreditor bisa melakukan hak eksekusinya karena dianggap sepihak dan dapat menimbulkan kesewenang-wenangan dari kreditor.

Mengingat pembiayaan atas barang objek fidusia biasanya tidak penuh sesuai dengan nilai barang. Atau, debitur sudah melaksanakan kewajiban sebagian dari perjanjian yang dilakukan, sehingga dapat dikatakan bahwa diatas barang tersebut berdiri hak sebagian milik debitor dan sebagian milik kreditor. Apalagi jika eksekusi tersebut tidak melalui badan penilai harga yang resmi atau badan pelelangan umum.

Situasi yang dapat terjadi yakni kreditor dalam eksekusi melakukan pemaksaan dan mengambil barang secara sepihak, padahal diketahui dalam barang tersebut sebagian atau seluruhnya milik orang lain. Walaupun juga diketahui bahwa sebagian dari barang tersebut adalah milik kreditor yang mau mengeksekusi tetapi tidak didaftarkan dalam di kantor fidusia. Bahkan pengenaan pasal-pasal lain dapat terjadi mengingat bahwa dimana-mana eksekusi merupakan bukan hal yang mudah, untuk itu butuh jaminan hukum dan dukungan aparat hukum secara legal. Bahkan apabila debitor mengalihkan benda objek fidusia yang dilakukan dibawah tangan kepada pihak lain tidak dapat dijerat dengan Undang-Undang 
No. 42 Tahun 1999 Tentang jaminan fidusia, karena tidak syah atau legalnya perjanjian jaminan fidusia yang dibuat.

\section{KESIMPULAN DAN SARAN}

Berdasarkan kegiatan penyuluhan ini diperoleh hasil bahwa berdasarkan ketentuan Pasal $30 \mathrm{UU}$ Fidusia "Pemberi Fidusia wajib menyerahkan benda yang menjadi objek jaminan dalam rangka pelaksanaan eksekusi jaminan Fidusi". Ketentuan Penjelasan dalam Pasal 30 UU Fidusia yang menyebutkan bahwa "dalam hal Pemberi Fidusia tidak menyerahkan benda yang menjadi objek Jaminan Fidusia pada waktu eksekusi dllaksanakan, Penerima Fidusia berhak mengambil benda yang menjadi objek Jaminan Fidusia dan apabila perlu dapat meminta bantuan pihak yang berwenang." maka dapat disimpulkan bahwa kreditor dapat mengambil objek jaminan tersebut secara paksa dengan catatan bahwa pengambilan tersebut melalui bantuan pihak yang berwenang. Kemudian kurangnya pengetahuan masyarakat gelogor mengenai executie obyek jaminan fiducia. Hal ini dapat terlihat dari antusian masyarakat dalam memberikan pertanyaan terkait meteri yang kami berikan. Serta masyarakat gelogor tidak mengetahui akibat hukum yang ditimbulkan dari tidak dilaksanakan kewajibannya pada bank. Sehingga banyak dari pemberi fidusia yang menggadaikan emasnya pada lembaga penggadaian dengan tujuan mengembalikan pinjaman yang menunggak tersebut. Kemudian masyarakat juga kurang memahai akibat lain dari tidak dilaksanakan kewajiban dari pemberi fidusia, yaitu barang jaminan, berupa benda

bergerak dilelang oleh lembanga perbankan, melalui Kantor Lelang Negara. Oleh karena itu disarankan agar di desa gelogor perlu diadakan penyuluhan hukum yang berkelanjutan untuk tema yang seperti ini.

\section{DAFTAR PUSTAKA}

Khoidin, M. (2017). Hukum Jaminan (Hak-Hak Jaminan, Hak Tanggungan dan Eksekusi Hak Tanggungan). Laksbang Justitia, Surabaya.

Utami, F.A. (2021). Apa itu Fidasia?. https://www.wartaekonomi.co.id/read321222/apa-itu-fidusia

Witanto. (2015). Hukum Jaminan Fidusia Dalam Perjanjian Pembiayaan Konsumen (Aspek Perikatan, Pendaftaran, dan Eksekusi). Mandar Maju, Bandung. 